\title{
KEDUDUKAN DAN PERLINDUNGAN SAKSI MAHKOTA DALAM TINDAK PIDANA PENCURIAN DENGAN KEKERASAN (Studi Kasus Pengadilan Negeri Denpasar)
}

\author{
Ni Made Elly Pradnya Suari, I Made Minggu Widyantara, Ni Made Sukaryati Karma \\ Fakultas Hukum Universitas Warmadewa, Denpasar - Bali, Indonesia
}

\begin{abstract}
Abstrak
Keberadaan saksi di dalam pembuktian menjadi kata kunci dalam pengungkapan fakta perkara pidana. Saksi mahkota sering dihadirkan di persidangan. Namun banyak perbedaan pendapat dalam Yurisprudensi mengenai penggunaan saksi mahkota dalam persidangan dikarenakan belum adanya pengaturan hukum yang secara tegas mengatur mengenai penggunaan saksi mahkota dalam peradilan pidana. Berdasarkan permasalahan tersebut penelitian ini menguraikan bagaimana perlindungan hak terdakwa sebagai saksi mahkota dalam tindak pidana pencurian dengan kekerasan dan bagaimana kedudukan saksi mahkota dalam tindak pidana pencurian dengan kekerasan. Penelitian ini didesain dengan menggunakan metode penelitian hukum normatif dan pendekatan konseptual. Dalam KUHAP tidak ada larangan seorang terdakwa memberikan keterangan untuk terdakwa lain sejauh menggunakan sistem splitsing sehingga terdakwa yang menjadi saksi mahkota tetap mendapatkan perlindungan hukum. Putusan Mahkamah Agung Nomor 1942 K/PID/2012 yang dalam proses pembuktiannya menggunakan saksi mahkota. Dalam hal ini jaksa penuntut umum menghadirkan saksi mahkota dikarenakan kurangnya alat bukti khususnya alat bukti keterangan saksi. Peranan saksi mahkota sangat penting untuk mengungkap peristiwa pidana karena terdakwa itulah yang mengetahui, melihat, dan melakukan tindak pidana pencurian dengan kekerasan. Maka disimpulkan perlindungan hak terdakwa sebagai saksi mahkota dipersamakan dengan hak terdakwa secara umum, yaitu diatur dalam Pasal 50 sampai dengan Pasal 68 KUHAP dan hak saksi yang diatur dalam Pasal 5 Undang-Undang Nomor 31 Tahun 2014. Kedudukan saksi mahkota dibenarkan dalam pembuktian didasarkan pada Surat Edaran Kejaksaan Agung Republik Indonesia Nomor B69/E/02/1997 Tahun 1997 Tentang Hukum Pembuktian Dalam Perkara Pidana.
\end{abstract}

Kata Kunci: Kedudukan, Perlindungan, Saksi Mahkota, Tindak Pidana

\begin{abstract}
The presence of witnesses in the evidence is the keyword in disclosing the facts of criminal cases. The crown witness is often present at court. However, there are many differences of opinion in the Jurisprudence regarding the use of crown witnesses in court because there is no legal regulation that explicitly regulates the use of crown witnesses in criminal justice. Based on these problems, this study described how the protection of the rights of defendants as crown witnesses in criminal acts of theft with violence and how the position of crown witnesses in criminal acts of theft with violence. This research was designed using a normative legal research method and a conceptual approach. In the Criminal Procedure Code, there is no prohibition for a defendant to provide information for other defendants as far as using a splitsing system so that defendants who are crown witnesses still receive legal protection. The decision of the Supreme Court Number $1942 \mathrm{~K} / \mathrm{PID} / 2012$ which in its verification process used a crown witness. In this case, the public prosecutor presented the crown witness due to the lack of evidence especially witness testimony evidence. The role of the crown witness is very important to uncover criminal events because the defendant knows, sees, and commits criminal theft with violence. The result of this study showed that the protection of the rights of the defendant as a crown witness is equated with the rights of the defendant in general, which is regulated in Article 50 to Article 68 of the Criminal Procedure Code and witness rights set out in Article 5 of Law Number 31 of 2014. The position of the crown witness is justified in proof-based on the Circular Attorney General's Office of the Republic of Indonesia Number B-69 / E / 02/1997 of 1997 concerning Proof Law in Criminal Cases.
\end{abstract}

Keywords: Position, Protection, Crown Witness, Crime 


\section{PENDAHULUAN}

Proses peradilan pidana itu menunjukkan adanya hubungan yang erat antara lembaga-lembaga penegak hukum, atau dengan kata lain membuktikan adanya suatu sistem peradilan pidana (Husin \& Husin, 2016). Mengenai sistem peradilan pidana ini diatur dalam Undang-Undang Nomor 8 Tahun 1981 tentang Kitab Undang-undang Hukum Acara Pidana (KUHAP). Dalam mengungkap suatu perkara dalam proses peradilan pidana, untuk memperoleh kebenaran materiil bahwa telah terjadinya tindak pidana itu perlu dilakukan proses pembuktian.

Jika dalam suatu peristiwa tindak pidana yang mana guna mengungkap fakta-fakta berkaitan dengan perbuatan pelaku atau pun tentang kronologis peristiwa pidana tersebut, sangat penting adanya keberadaan saksi yang melihat, mendengar, dan yang mengalami sendiri hal tersebut. Namun apabila tidak adanya saksi yang memenuhi syarat tersebut, maka akan sangat sulit dalam mengungkap faktafakta dalam peristiwa tersebut. Oleh karena itu, jaksa penuntut umum menghadirkan saksi mahkota dalam proses persidangan karena saksi mahkota merupakan salah satu terdakwa yang dijadikan saksi dalam perkara yang dianggap mengetahui dan mengalami tindak pidana tersebut.

Terkait dengan keadaan tersangka sebagai saksi (saksi mahkota), haruslah diberikan perlindungan hukum agar kesaksiannya berdampak positif terhadap dirinya, misalnya dikurangi hukumannya oleh pengadilan atau dituntut ringan atau bahkan dibebaskan oleh Jaksa Penuntut umum. Kaitannya dengan hal tersebut di atas bila tidak adanya saksi pengungkap fakta misalnya salah satu contoh kasus seperti kasus pencurian dengan kekerasan yang dalam proses pembuktiannya menggunakan saksi mahkota sebagai alat bukti, yaitu kasus yang telah diputuskan oleh Pengadilan Negeri Denpasar dengan Putusan Kasasi Nomor: 1942 K/PID/2012. Terkait masalah saksi yang dihadirkan Jaksa Penuntut Umum, ada satu (1) saksi mahkota yang dihadirkan dalam persidangan, yaitu Endro Widio Seno yang sekaligus menjadi terdakwa dalam perkara yang sama namun penuntutan dilakukan dengan berkas terpisah (Splitsing). Saksi ini mengetahui dan melihat sendiri perkara pencurian dengan kekerasan dikarenakan saksi merupakan terdakwa dari perkara tersebut.

Penggunaan saksi mahkota di Indonesia masih menjadi perbincangan oleh para praktisi hukum dikarenakan belum adanya pengaturan hukum terkait penggunaan saksi mahkota ini. Bukan hanya terbatas akan hal tersebut, penggunaan atau penerapan kesaksian dari saksi mahkota pun tertuang dalam beberapa yurisprudensi Mahkamah Agung.

Berdasarkan latar belakang masalah di atas yang telah diuraikan, maka penelitian ini dilakukan untuk mendeskripsikan bagaimana perlindungan hak terdakwa sebagai saksi mahkota dalam tindak pidana pencurian dengan kekerasan dan bagaimana kedudukan saksi mahkota dalam tindak pidana pencurian dengan kekerasan.

\section{METODE PENELITIAN}

Desain penelitian ini dilakukan dengan menggunakan pendekatan penelitian hukum normatif karena pengkajiannya dilakukan dengan studi kepustakaan yaitu berupa bahan-bahan hukum. Karena ini adalah penelitian hukum normatif, pendekatan masalah yang digunakan adalah pendekatan perundang-undangan dan pendekatan konseptual. Sumber bahan hukum yang diperoleh adalah bahan hukum primer terdiri dari perundang-undangan, catatan resmi atau risalah dalam pembuatan perundang-undangan dan putusan- putusan hakim yang telah mendapatkan keputusan hukum tetap, bahan hukum sekunder, yaitu penjelasan mengenai bahan hukum primer, misalnya wawancara, buku ilmu hukum, jurnal-jurnal hukum dan juga internet yang berkaitan dengan saksi mahkota dalam tindak pidana pencurian dengan kekerasan sebagai permasalahan yang dibahas, dan bahan hukum tersier, yaitu bahan hukum yang digunakan dan dianalisas dari kamus hukum, encylopedia dan bahan tulis lainnya yang berkaitan dengan isu hukum yang diteliti.

Teknik pengumpulan bahan hukumyang digunakan dalam penelitian ini yaitu: teknik studi dokumen, digunakan dengan cara melakukan pencatatan terhadap sumber bahan hukum primer dan bahan hukum sekunder kemudian akan dilakukan melalui penelusuran melalui kepustakaan yang berkaitan dengan perlindungan hukum terhadap konsumen, studi kepustakaan, yakni teknik pengumpulan bahan hukum dengan mengalisasi bahan hukum seperti buku dan catatan- catatan berkaitan dengan isu hukum yang dibahas dalam penelitian ini, dan studi internet, yakni teknik yang mempergunakan informasi atau bahan hukum yang berasal atau dikutip dari tulisan-tulisan website pemerintah atau website terpercaya. 
Analisis bahan hukum dilakukan setelah seluruh bahan-bahan hukum yang dibutuhkan sudah terkumpul. Kemudian dalam pembahasan selanjutnya bahan hukum tersebut diolah serta dianalisis. Bahan hukum yang diperoleh suatu kebenaran untuk berusaha memahami kebenaran tersebut. Setelah data yang perlu terkumpul, penafsirkan atau penginterpretasikan secara sistematis dan terstruktur dilakukan dengan memberikan argumentasi serta solusi terhadap permasalahan kekaburan norma yang dapat ditarik dengan kesimpulan.

\section{HASIL PENELITIAN DAN PEMBAHASAN Perlindungan Hak Terdakwa Sebagai Saksi Mahkota Dalam Tindak Pidana Pencurian Dengan Kekerasan}

Tindak pidana adalah suatu perbuatan yang dilakukan oleh manusia yang melanggar norma atau aturan hukum yang berlaku sehingga dirinya dipersalahkan atas perbuatan itu dan menyebabkan kerugian terhadap pihak lain baik berupa materiil ataupun immaterial yang disertai dengan ancaman sanksi pidana oleh Undang-Undang yang terkait. Adapun pencurian yang dalam bentuk pemberatan, artinya pencurian yang dirumuskan sebagaimana berdasarkan dengan ketentuan Pasal 362 KUHP yang ditambah dengan unsur-unsur secara obyektif dan subyektif yang bersifat pemberatan terhadap tindak pidana pencurian tersebut dan karenanya diberikan ancaman pidana yang lebih berat dalam bentuk pokoknya. Dalam hal ini, Pasal 365 KUHP merupakan pencurian dalam bentuk pemberatan dimana dalam pencurian tersebut disertai dengan kekerasan atau ancaman kekerasan. Ancaman kekerasan adalah perbuatan yang dilakukan untuk menimbulkan rasa sakit atau luka, yang sebelumnya dilakukan untuk menimbulkan ketakutan dan rasa cemas dari korban.

Saksi adalah seorang yang memiliki informasi berdasarkan pengalaman yang langsung ia lihat, dengar, dan alami sendiri berkaitan dengan fakta hukum yang terjadi, dan biasanya hal tersebut pula mengenai suatu tindak pidana sehingga saksi sangat diperlukan dalam proses persidangan di pengadilan dan membantu memastikan pertimbangan-pertimbangan terkait suatu kejahatan atau kejadian. Suatu keterangan saksi adalah alat bukti yang berkaitan dengan perkara pidana yang merupakan keterangan dari orang (saksi) yang melihat sendiri, mendengar sendiri dan mengalami sendiri suatu peristiwa hukum. Keterangan saksi tidak termasuk keterangan yang diperoleh dari orang lain atau testimonium de auditio atau hearsay evidence (penjelasan Pasal 185 ayat 1 KUHAP) (Harahap, 2012).

Adanya alat bukti berupa keterangan saksi dalam suatu pemeriksaan dalam persidangan pidana tidak dapat dihindari karena semua proses pemeriksaan tindak pidana dari awal di kepolisian sampai dengan dalam suatu persidangan tidak pernah luput dari keterangan saksi yang mengetahui fakta dan peristiwa hukum yang terjadi sehingga nilai keterangan saksi tersebut sangat kuat dalam pembuktian pidana. Pemahaman mengenai saksi mahkota adalah dimana seorang terdakwa dijadikan saksi bagi terdakwa lainnya. Hal ini terkadang dilakukan dalam praktik berkaitan dengan peristiwa hukum yang melibatkan banyak terdakwa, sehingga terdakwa lainnya memberi keterangan bagi terdakwa lainnya mengenai kronologis persiapan sampai dengan terjadinya tindak pidana karena saksi mahkota terlibat langsung dalam proses (tindak pidana) tersebut.

Pada dasarnya saksi mahkota ini dapat digunakan dalam tindak pidana penyertaan (deelneming), dilakukan berkas perkara terpisah (splitsing), dan kurangnya alat bukti yang diajukan oleh jaksa penuntut umum, khususnya alat bukti keterangan saksi (Anggasakti \& Kawa, 2016; Sukadana, Amiruddin, \& Parman, 2018; Yusman, 2019). Hal ini bertujuan agar terdakwa tidak terlepas dari pertanggung jawabannya sebagai pelaku perbuatan pidana. Mengenai masalah perlindungan hukum terhadap hak-hak terdakwa yang menjadi saksi dalam suatu persidangan merupakan suatu hal yang penting dimana setiap orang/ warga negara Indonesia mempunyai hak untuk dilindungi oleh pemerintah. Hal ini ditegaskan dalam Bab XA UUD NRI 1945 Pasal 28A sampai dengan Pasal 28J yang merupakan pengakuan negara terhadap perlindungan hak asasi manusia.

Dengan dijaminnya perlindungan akan kedudukan tersangka dalam semua tingkat pemeriksaan, hal ini menunjukan bahwa KUHAP menganut sistem akusatoir. Artinya KUHAP menempatkan seorang tersangka sebagai subjek hukum dengan segala hak yang melekat padanya (Asmasasmita, 2011). Terkait dengan hal ini maka tersangka yang menjadi saksi mahkota dalam proses pembuktian hingga dalam persidangan kedudukan dan perlindungan hukumnya sama seperti saksi pada umumnya. 
Mengenai keringanan yang diberikan kepada saksi mahkota terhadap keterangan yang telah ia berikan dalam persidangan dapat berupa peniadaan tuntutan atau berupa keringanan hukuman berdasarkan dengan pertimbangan majelis hakim yang mengadili. Perlindungan hukum terhadap saksi mahkota dipersamakan dengan perlindungan saksi secara umum dikarenakan belum adanya pengaturan hukum yang secara tegas mengatur tentang penggunaan saksi mahkota (Amiruddin, 2017; Ismail, 2018; Siahaan, 2015; Syamsuningsih, 2016). Mengenai hak terdakwa yang diatur didalam KUHAP, tidak ada larangan kepada seorang terdakwa memberikan keterangan untuk terdakwa lain apabila menggunakan system pemisahan berkas (splitsing).

\section{Kedudukan Saksi Mahkota Dalam Tindak Pidana Pencurian Dengan Kekerasan}

Kehadiran saksi mahkota dalam sidang di pengadilan masih menjadi perbincangan hingga saat ini. Dalam KUHAP tidak diatur jelas mengenai konsep atau adanya saksi mahkota dalam suatu pemeriksaan baik dari kepolisian sampai dengan pengadilan. Namun dalam ketentuan Pasal 168 KUHAP, pula tidak melarang orang yang bersama-sama melakukan tindak pidana untuk memberikan keterangannya sebagai saksi bagi tersangka atau terdakwa lainnya. Seiring dengan perkembangan zaman maka sangat mendesak adanya saksi mahkota guna membuktikan mengenai peristiwa hukum yang sebenarnya terjadi.

Terkait penghargaan yang diberikan atas kesaksian yang telah diberikan tersebut dapat saja berupa pemberian keringanan dalam proses pemidanaan yakni dalam putusan atau bahkan adanya proses pembebasan bersyarat, remisi dan hak-hak terdakwa lainnya yang disesuaikan dengan pertimbangan- pertimbangan majelis hakim. Berdasarkan dengan Surat Edaran Kejaksaan Agung Nomor B-69/E/02/1997 Tahun 1997 tentang Hukum Pembuktian Dalam Perkara Pidana memberikan penjelasan mengenai saksi mahkota (Muharikin, 2015). Dalam Kitab Undang-undang Hukum Acara Pidana (KUHAP) tidak diatur secara tegas mengenai kedudukan terdakwa sebagai saksi bagi terdakwa lain dalam melakukan perbuatan pidana secara bersama-sama, baik sebagai pelaku, membantu melakukan atau turut serta melakukan peristiwa pidana tersebut.

Saksi mahkota memiliki peran penting dalam proses pembuktian dalam suatu pengungkapan peristiwa pidana yang terjadi. Saksi mahkota biasanya adalah seorang tersangka/ terdakwa yang memiliki peran paling ringan dalam suatu tindak pidana yang dilakukan bersama-sama sehingga dengan perannya sebagai saksi mahkota, maka ia akan diberikan keringanan hukum atau bisa saja dikeluarkan dari daftar tersangka atau terdakwa berdasar pertimbangan dari penyidik atau majelis hakim (Firdaus, 2015).

Salah satu contoh kasus yang menghadirkan saksi mahkota dalam proses pembuktian di dalam persidangan adalah kasus pencurian dengan kekerasan yang sudah diputuskan di Pengadilan Negeri Denpasar dengan putusan kasasi nomor 1942K/Pid B/2012. Dari hal ini jaksa penuntut umum dalam dakwaan kasasi menghadirkan saksi mahkota, yaitu Endro Widio Seno yang merupakan salah satu terdakwa tindak pidana pencurian dengan kekerasan. Endro Widio Seno hanya ikut serta dalam tindak pidana pencurian dengan kekerasan sehingga paling ringan ancaman pidananya dikarenakan ia tidak melakukan kekerasan atau ancaman kekerasan. Ia hanya ikut serta dalam mobil yang dipakai melakukan tindak pidana tersebut. Selain itu, Endro Widio Seno juga terlibat langsung dalam tindak pidana tersebut tentunya hal ini dapat meringankan atau memberatkan terdakwa lainnya. Berdasarkan hal itu maka Endro Widio Seno dijadikan saksi mahkota dengan memberikan kesaksian terhadap terdakwa lainnya dengan menggunakan sistem pemisahan berkas perkara (splitsing).

Mengenai keterangan saksi mahkota sebenarnya adalah pemeriksaan terhadap terdakwa yang diberikan posisinya menjadi saksi untuk terdakwa lainnya. Hal itu dikarenakan tidak adanya cukup alat bukti berdasarkan Pasal 183 KUHAP. Jadi, jaksa penuntut umum akan melakukan pemisahan berkas terhadap para terdakwa sehingga masing-masing dari terdakwa dapat memberikan kesaksiaanya kepada terdakwa lainnya sehingga terpenuhinya ketentuan dalam Pasal 183 KUHAP (Harahap, 2012).

Tugas jaksa penuntut umum adalah untuk membuktikan kepada hakim di depan persidangan pengadilan, bahwa benar-benar telah terjadi tindak pidana dan pelakunya adalah sebagaimana tertuang dalam surat dakwaan. Namun demikian, apa yang dibuktikan oleh jaksa penuntut umum akan diuji oleh hakim tentang sejauh mana kebenarannya serta alat-alat bukti apa yang mendukung pernyataan atau keterangan tersebut. 
Maka adanya pemeriksaan saksi mahkota yang diajukan oleh jaksa penuntut umum dengan metode pemisahan berkas perkara semata-mata hanyalah untuk memberikan keyakinan kepada majelis hakim, dengan keterangan dari terdakwa untuk mengungkap fakta-fakta hukum dari peristiwa pidana yang terjadi. Mengenai kedudukan terdakwa dalam pemberian kesaksian sebagai saksi mahkota berdasarkan KUHAP terdapat pertentangan norma dalam ketentuan Pasal 189 ayat (3) KUHAP, dalam ketentuan Pasal 189 ayat (3) KUHAP menyatakan bahwa keterangan terdakwa hanya dipergunakan terhadap dirinya sendiri, sehingga keterangan yang disampaikan terdakwa untuk terdakwa lainnya seharusnya tidak dapat didengar dan dijadikan kesaksian walaupun masing- masing terdakwa melakukan peristiwa atau tindakan pidana yang masih bertautan (Firdaus, 2015).

Pandangan yang membenarkan pemeriksaan saksi mahkota antara lain tertuang dalam Yurisprudensi Mahkamah Agung Nomor 1986/K/Pid/1989 tanggal 21 Maret 1990. Berdasarkan putusan tersebut bahwa Undang-Undang tidak melarang jaksa penuntut umum mengajukan saksi mahkota dengan syarat dan kondisi tertentu bahwa saksi ini dalam kedudukannya sebagai terdakwa tidak termasuk dalam satu berkas perakara dengan terdakwa yang diberikan kesaksian. Dalam hal ini jelas peranan saksi mahkota adalah sangat penting untuk mengungkap peristiwa pidana, karena tersangka/ terdakwa itulah yang mengetahui, melihat atau merasakan bahkan ikut melakukan tindak pidana itu dengan orang lain secara bersama-sama.

Berdasarkan Surat Edaran Kejaksaan Agung Republik Indonesia Nomor B-69/E/02/1997 tentang Pembuktian dalam perkara Pidana yang menyatakan bahwa saksi mahkota dapat digunakan dalam proses pembuktian dengan berdasarkan ketentuan khusus, yakni adanya tindak pidana penyertaan, dilakukan dengan sistem pemisahan berkas, dan dikarenakan kurangnya atau minimnya alat bukti khususnya alat bukti keterangan saksi. Mengenai keterangan saksi mahkota yang diajukan jaksa penuntut umum ke muka persidangan bukanlah masalah. Selama majelis hakim yang menyidangkan perkara tersebut menganggap penting kesaksian dari saksi mahkota tersebut, maka sedapat mungkin kesaksian mahkota tersebut pula harus didukung dengan adanya alat- alat bukti lainnya sehingga memberikan keyakainan tambahan bagi majelis hakim. Terkait persoalan melanggar hak asasi manusia, sejauh terdakwa tidak keberatan dan tidak dibawah paksaan saat menjadi saksi mahkota, hak seorang terdakwa tidak dilanggar dan tidak akan melanggar hak asasi terdakwa tersebut.

\section{SIMPULAN DAN SARAN}

1. Simpulan

Berdasarkan uraian di atas, dapat dibuat simpulan untuk memberikan pernyataan terkait hasil penelitian. Simpulannya adalah pertama, perlindungan hak terdakwa sebagai saksi mahkota dalam tindak pidana pencurian dengan kekerasan, belum ada Undang-Undang Khusus yag mengatur mengenai hal tersebut di dalam peradilan pidana, tetapi haknya sebagai saksi sama dengan saksi lainnya. Terkait dengan hal ini maka tersangka yang menjadi saksi mahkota dalam proses pembuktian hingga dalam persidangan memperoleh perlindungan yang sama seperti saksi pada umumnya yang diatur didalam Pasal 5 Undang-Undang Nomor 31 Tahun 2014 Tentang Perlindungan Saksi dan Korban. Mengenai perlindungan hak terdakwa diatur dalam Pasal 50 sampai Pasal 68 KUHAP. Kedua, kedudukan saksi mahkota dalam tindak pidana pencurian dengan kekerasan tidak diatur secara tegas dalam KUHAP mengenai saksi mahkota. Ada perbedaan pendapat oleh para praktisi hukum hingga perbedaan pendapat di dalam Yurispudensi mengenai penggunaan saksi mahkota ini. Meskipun demikian, hakim bisa menjadikan saksi mahkota sebagai dasar pertimbangan hakim di dalam memutuskan perkara tersebut. Dalam hal ini tindak pidana yang dilakukan berupa tindak pidana penyertaan dengan menggunakan sistem pemisahan berkas (splitsing) dikarenakan kurangnya alat bukti keterangan saksi.

\section{Saran}

Adapun saran yang dapat diberikan berdasarkan pembahasan penelitian ini, pertama, mengenai perlindungan hak terdakwa sebagai saksi mahkota dalam tindak pidana pencurian dengan kekerasan perlu adanya pengaturan hukum mengenai perlindungan saksi mahkota dalam persidangan yang bertujuan adanya kepastian hukum, kemanfaatan hukum, keadilan hukum, dan jaminan hukum sebagai unsur penegakkan hukum mengenai perlindungan kepentingan manusia. Kedua, mengenai kedudukan saksi mahkota dalam tindak pidana pencurian dengan kekerasan perlu adanya kebijakan 
hukum yang baru dalam bentuk pengaturan hukum mengenai saksi mahkota agar tidak lagi terjadinya perbedaan pendapat dalam Yurisprudensi tentang kebolehan penggunaan saksi mahkota.

\section{DAFTAR PUSTAKA}

Amiruddin, M. (2017). Peran Saksi Mahkota dalam Perkara Pidana Korupsi di Pengadilan Negeri Makassar. Jurisprudentie, 4(2), 137-145.

Anggasakti, T., \& Kawa, A. P. (2016). Penggunaan Saksi Mahkota dalam Pembuktian Perkara Pembunuhan Berencana Berdasarkan Asas Praduga Tidak Bersalah. Jurnal Verstek, 4(2), 200208.

Asmasasmita, R. (2011). Sistem Peradilan Pidana Kontemporer. Jakarta: Kencana Prenada Media Group.

Firdaus, A. S. (2015). Kedudukan Terdakwa sebagai Saksi (Saksi Mahkota) terhadap Terdakwa Lain dalam Tinjauan Hukum Acara Pidana. Fakultas Hukum Universitas Esa Unggul, 12(3), 227.

Harahap, Y. M. (2012). Pembahasan Permasalahan dan Penerapan KUHP Pemeriksaan Sidang Pengadilan, Banding, Kasasi, dan Peninjauan Kembali (II). Jakarta: Sinar Grafika.

Husin, K., \& Husin, B. R. (2016). Sistem Peradilan Pidana di Indonesia. Jakarta: Sinar Grafika.

Ismail. (2018). Peranan Saksi Mahkota dalam Proses Pembuktian Perkara Pidana di Indonesia (Universitas Hasanuddin).

Muharikin, I. M. (2015). Kedudukan Saksi Mahkota dalam Proses Peradilan Pidana di Indonesia Berdasarkan Asas Non Self Incrimination. Fakultas Hukum Universitas Brawijaya, 9.

Siahaan, B. (2015). Kajian Yuridis tentang Saksi Pengungkap Fakta (Whistleblower). Lex Crimen, IV(1), 178-187.

Sukadana, I. M., Amiruddin, A., \& Parman, L. (2018). Alat Bukti Keterangan Saksi Mahkota Dalam Perkara Pidana Pencurian. Law Reform, 14(2), 262-274.

Syamsuningsih, S. N. (2016). Perlindungan Hukum terhadap Saksi Mahkota dalam Perkara Tindak Pidana Korupsi. E Journal Katalogis, 4(7), 1-12.

Yusman. (2019). Saksi Mahkota dalam Proses Penyelesaian Perkara (Splitsing) dalam Perkara Tindak Pidana Korupsi. RECHTSREGEL Jurnal Hukum, 2(1), 509-524. 